Available online at GSC Online Press Directory

GSC Biological and Pharmaceutical Sciences

e-ISSN: 2581-3250, CODEN (USA): GBPSC2

Journal homepage: https://www.gsconlinepress.com/journals/gscbps

(RESEARCH ARTICLE)

\title{
Reserves of nutrients and soil organic components of Haplic Chernozems
}

\author{
Nankova Margarita Ivanova ${ }^{1, *}$ and Filcheva Ekaterina Georgieva ${ }^{2}$ \\ ${ }^{1}$ Dobrudzha Agricultural Institute - General Toshevo, Bulgaria. \\ ${ }^{2}$ N. Pousnkarov Institute of Soil Science, Agrotechnology and Plant Protection - Sofia, Bulgaria.
}

Publication history: Received on 29 April 2020; revised on 05 May 2020; accepted on 06 May 2020

Article DOI: https://doi.org/10.30574/gscbps.2020.11.2.0119

\begin{abstract}
The focus of this investigation is to present the reserves, soil nutrients and organic matter components along the profile depth of Haplic Chernozems near village Krupen, Kavarna municipality, South Dobrudzha region. The data confirm our previous investigations that they are one of the most fertility soils in Bulgaria. The profile is also marked by a variation of nutrients reserves according to the genetic horizon. All investigated reserves gradually decreased which is typical for the group of izohumic soils. The $\mathrm{N}_{\text {total }}$ reserves varied from $66.37 \%$ in $A_{\text {horizon }}$ to $8.86 \%$ in $C_{\text {horizon }}$ of the total stocks counting to $3.247 \mathrm{~kg} / \mathrm{ha}$. The reserves of total phosphorus in $\mathrm{A} 0-84 \mathrm{~cm}$ add up to $1.723 \mathrm{~kg} / \mathrm{m}^{2}$, which is $45.94 \%$ from the total reserves of through profile, while in soil formation material horizon (C $(20.85 \%)$. The $C_{\text {org }}$ reserves in the study profile $(0-195 \mathrm{~cm})$ are $326.131 \mathrm{~kg} / \mathrm{m}^{2}$ and $67.50 \%$ of the stocks are concentrated in the humus accumulative horizon. In transition horizon (B84-152) all nutrient reserves gradually decreased and reached lowest values in soil formation material horizon $\left(\mathrm{C}_{152-195}\right)$. These two genetic horizons have a higher degree of enrichment of humus with nitrogen compared to the humus-accumulative horizon. Throughout the depth of the profile, the degree of enrichment of humus with nitrogen is defined as "average". We established essential correlations between the investigated indices as follows: Reserves of C-total are in a strong correlation with reserves of $\mathrm{N}$-total $\left(0.993^{* *}\right)$; Cres. $\left(0.982^{* *}\right)$; C-тно $\left(0.949^{* *}\right)$; Mineralization ability after 56 days incubation $\left(0.665^{* *}\right)$ and exchable potassium.
\end{abstract}

Keywords: Virgin profile; Haplic Chernozems; organic carbon reserves

\section{Introduction}

A primary understanding of soil is achieved through the study of the soil profile, interactions of soil material with organisms, and the movement of water through the soil profile by leaching. An essential function of soil is the break down of organic material to form soil humus and release nutrients that can be utilized by soil organisms and growing plants. Soil is also an important reservoir of the Earth's biodiversity, containing higher species and functional biodiversity than any other portion of terrestrial ecosystems.

As the interface between the atmosphere, biosphere, and lithosphere, soil undergoes an intense vertical exchange of materials resulting in steep chemical and physical gradients from surface to bedrock. The type, thickness, and position of horizons can yield information about soil forming factors such as climate, topography, and vegetation type [1]. Soils represent the most important long-term organic carbon (OC) reservoir in terrestrial ecosystems, as they contain more $\mathrm{C}$ than plant biomass and the atmosphere [2]. The large soil reservoir is not permanent results from a dynamic equilibrium between organic and inorganic material entering and leaving the soil. Soil $\mathrm{C}$ is further sensitive to environmental changes such as global warming or nitrogen deposition [3]. Soils represent the most important longterm organic carbon (OC) reservoir in terrestrial ecosystems, as they contain more $\mathrm{C}$ than plant biomass and the atmosphere $[4,5]$. The large soil reservoir is not permanent but results from a dynamic equilibrium between organic

\footnotetext{
${ }^{*}$ Corresponding author: Nankova Margarita Ivanova
}

Copyright (C) 2020 Author(s) retain the copyright of this article. This article is published under the terms of the Creative Commons Attribution Liscense 4.0. 
and inorganic material entering and leaving the soil. Therefore, $\mathrm{C}$ stored in soils is affected by changes in vegetation and plant growth, removal of biomass by harvest, and mechanical soil disturbances such as plowing.

The manifold importance of nutrients and organic matter in soil formation and soil fertility has been demonstrated by the experience of agriculture over many centuries and by numerous investigations, in which the role of organic matter in soil processes (weathering, soil profile formation, soil structure formation, etc.) as well as in supplying plants with nutrients and biologically active substances has been elucidated [6, 7].

Dokuchaev [8, 9] defined Chernozem as a zonal soil formed under steppe and dry continental climates on loess parent material. In literature, the "Chernozem" was probably mentioned for the first time in 1645 by Salmon Gubert [10]. Chernozem is an iconic soil. Because Chernozem is a symbol of fertility, it has always been a centre of high interest for agronomists and pedologists [11]. Chernozems cover an estimated 230 million hectares worldwide, mainly in the middle latitude steppe of Eurasia and North America, north of a zone with Kastanozems. Traditionally, Chernozems are ranked as undifferentiated by the material composition of soil. Under conditions of circulation of hydrocarbonatecalcium solution in Chernozems, its aggressiveness is bare enough to wash out and redistribute calcium carbonates in the soil profile. At the same time, soil processes that actively destroy and redistribute the silicate part of the mineral composition of Luvic Greyzemic Chernozems seem not to take place (such as podzolization) or are slightly noticeable (gleyzation, lessivage, mole draining). In general terms, these statements are true only for Haplic Chernozems [12].

Soil nutrition reserves including and carbon stocks are strongly controlled by the climate and land cover. These main drivers, especially the land use patterns are changing rapidly by human activities. The climate and land-use changes are significantly visible, and their impacts on terrestrial ecosystems are increasingly being studied [13]. Climatic conditions have the main impact on vegetation and crop management, which also has influence over soil organic matter content [14].

Soil formation processes in all Chernozems, determined relatively good conditions for humus formation and humus accumulation. These processes in Bulgarian Chernozems are expressed significantly less compared to classical Chernozem's zone of Russia. Soil organic matter has a favourable composition and properties. The subtypes of Chernozems with their specific characteristics and in accordance with the humus distribution along the profile depth, organic carbon stocks were detailed described in the well known Bulgarian researchers Artinova, Gribachev, Jolevski; Krastanov, Gerasimov, in Soil survey; Filcheva [15, 16, 17], Petrova, Shishkov and expecially for Dobroudja region articles, published of Nankova [18, 19, 20, 21, 22, 23, 24, 25, 26, 27, 28, 29, 30, 31, 32, 33, 34, 35, 36, 37].

Features of generalized profiles of subtypes of Chernozems in different land use: arable, virgin and under forest with profile distribution of organic carbon, organic matter fraction, organic carbon stocks were described in details (Filcheva, $2004,2007,2015)$. The latest investigation grouped the Chernozems in the group of Izohumic soils and was presented their main characteristics $[15,16,17,38,39,40,41]$.

The focus of our investigation is to present the reserves of soil nutrients and organic matter components of a virgin Haplic Chernozems profile, situated in the eastern part of geographical region South Dobrudzha (Bulgaria) near the village of Krupen municipality of Kavarna town.

\section{Material and methods}

The investigation was carried out on the territory of AGROSPECTOR LTD in the region of Village Krupen municipality of Kavarna town (N 4334'22.43"'- E 28 14'45.59”) at elevation of 173 meter. Complete characteristics of the virgin profile was made from Prof. Shishkov [42].

In geological terms, this region of the Dobrudzha plateau is built on the lower and the middle-Sarmatian sediments, made up of alternating sandy limestones and marls with the aquiferous flow that run through in them (Figure 1). 

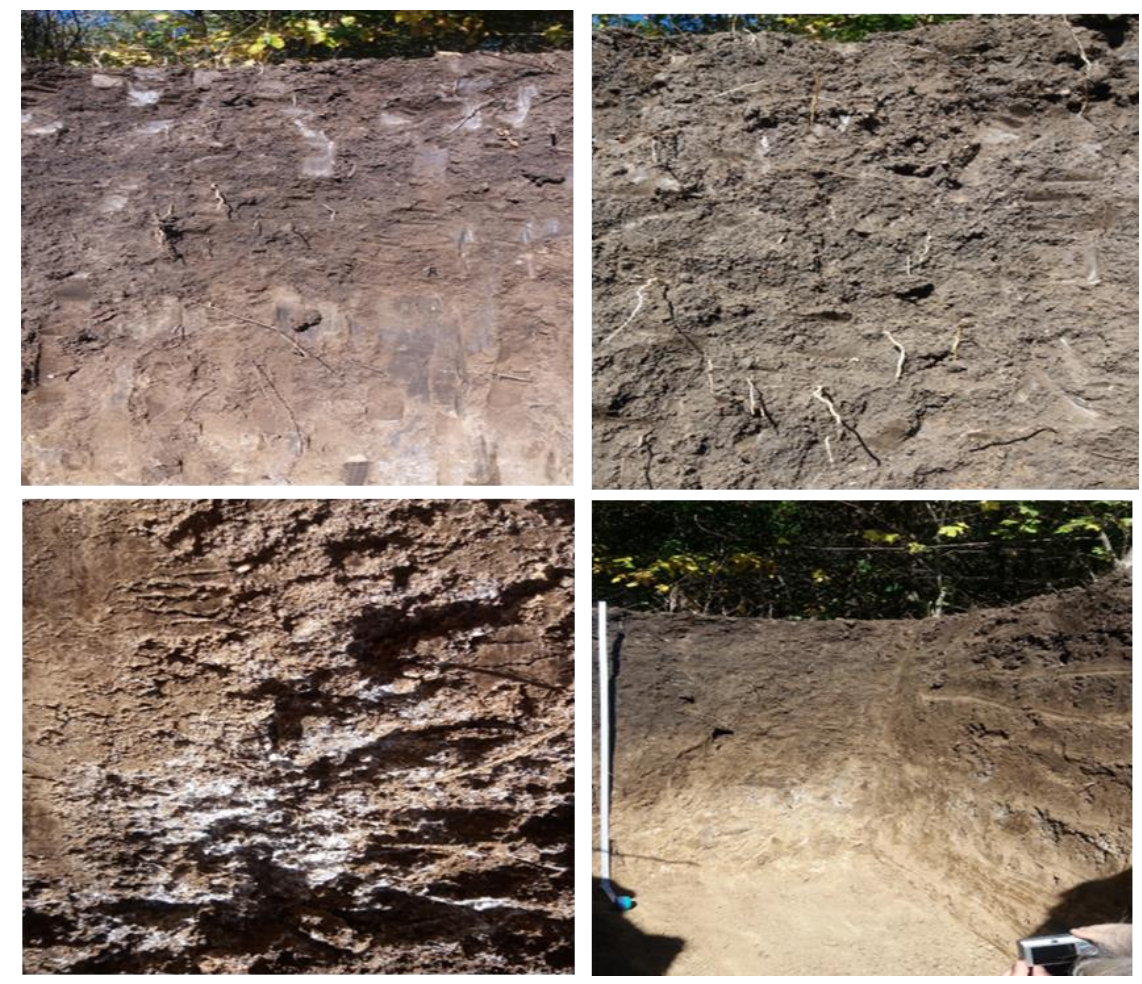

Figure 1 Profile photos

The analytical data for the agrochemical characteristic of the mobile and total forms of the basic macroelements as well as the mineralization capacity and organic $C$ of the soil were prepared according to the requirements of each specific analysis. The content of studied components of soil samples was determined as follow:

- $\quad$ Soil acidity was determined in water and salt suspension (1 $\mathrm{n} \mathrm{KCl)} \mathrm{[43].}$

- The mineral nitrogen forms in soil and their sum were determined by extraction with $1 \% \mathrm{~K}_{2} \mathrm{SO}_{4}$ (mg/1000 g soil). The identification of $\mathrm{NO}_{3}-\mathrm{N}$ in the filtrate was done using the disulfophenol method, and ammonium nitrate was determined through the phenol method [44].

- The potential nitrogen-supplying ability of soil was determined through incubation under constant temperature of $30^{\circ} \mathrm{C}$ at $60 \%$ humidity from its total moisture absorption capacity in order to develop optimal conditions for nitrification. Incubation was done in a thermostat to investigate its dynamics at the $14^{\text {th }}, 28^{\text {th }}$ and $56^{\text {th }}$ day. The samples were analyzed to determine the amount of nitrate nitrogen in $1 \% \mathrm{~K}_{2} \mathrm{SO}_{4}$ extract. The ability of $\mathrm{NO}_{3}-\mathrm{N}$ to form intensive yellow coloration when interacting with disulphurphenolic acid $\left[\mathrm{C}_{6} \mathrm{H}_{3} \mathrm{OH}\left(\mathrm{HSO}_{3}\right)_{2}\right]$ in alkali media was used [44].

- Available phosphorus and the exchangeable potassium were determined by AL-method [45]. Phosphorus available to plants (mg $\mathrm{P}_{2} \mathrm{O}_{5} / 100 \mathrm{~g}$ soil) was determined calorimetrically, and the amount of exchangeable potassium (mg $\mathrm{K}_{2} \mathrm{O} / 100 \mathrm{~g}$ soil) through flame photometry.

- The total nitrogen content in soil (mg/100 g) was determined by the method of Kjeldahl after wet burning with concentrated $\mathrm{H}_{2} \mathrm{SO}_{4}$ diluted in distilled water at ratio 1:10, followed by distillation of nitrogen in Parnas-Wagner distillation apparatus.

- $\quad$ Total phosphorus content (\%) was determined according to Bone method [44].

- Soil organic matter composition was determined by the method of Kononova-Belchikova [6, 46]. Total humic and fulvic acids (Cextr.) after extraction with mixed solution of $0.1 \mathrm{M} \mathrm{Na} \mathrm{P}_{2} \mathrm{O}_{7}$ and $0.1 \mathrm{M} \mathrm{NaOH}$; "free" and $\mathrm{R}_{2} \mathrm{O}_{3}$ bounded humic and fulvic acids $\left(\mathrm{C}_{\mathrm{NaOH}}\right)$ after extraction with $0.1 \mathrm{M} \mathrm{NaOH}$ and the most dynamic, low molecular fraction of organic matter, so called "aggressive" fulvic acids fraction - 1a extracted with $0.05 \mathrm{M} \mathrm{H}_{2} \mathrm{SO}_{4}$, ratio soil 
: solution=1:20 for the three extractions. Humic and fulvic acids in both extracts $\mathrm{C}_{\mathrm{extr}}$. and $\mathrm{C}_{\mathrm{NaOH}}$ were separated by acidifying the solution with sulfuric acid $(0.5 \mathrm{M})$.

- $\quad$ Nutrient reserves were calculated by [47]: $A=H \cdot V \cdot X$.

Where: $A$ is the reserve of organic matter, $\mathrm{kg} / \mathrm{ha}(\mathrm{t} / \mathrm{ha}) ; H$ is the thickness of soil layer, $\mathrm{cm}$; $V$ is the soil density and $X$ is the element content, $\%$.

The data were analyzed using the software packages Microsoft Excel and SPSS software (Ver. 22, 2013). Relationships between investigated indices were estimated using the mean values, standard errors, analysis of variance (two-way ANOVA) and Pearson's correlation coefficients; significant differences between soil layers were determined at $\mathrm{P} \leq 0.05$ and $\mathrm{P} \leq 0.01$.

\section{Results and discussion}

The results from the multifactor analysis of variances, based on the ANOVA, of the reserves of investigated agrochemical indices revealed high statistical significance over soil depth (Table 1).

Precise determination of changes in organic carbon (OC) stocks is prerequisite to understand the role of soils in the global cycling of carbon and to verify changes in stocks due to the management [48].

Table 1 Varians analysis of the reserves of agrochemical indices

\begin{tabular}{llllll}
\hline Dependent Variable & Type III Sum of Squares & df & Mean Square & F & Sig. \\
\hline $\mathrm{NH}_{4}$ & 895581.146 & 9 & 99509.016 & 9.777 & .001 \\
$\mathrm{NO}_{3}$ & 28431.864 & 9 & 3159.096 & 206.082 & .000 \\
$\mathrm{Min} . \mathrm{N}$ & 1174185.641 & 9 & 130465.071 & 12.822 & .000 \\
Pure MA-56 days & 187.621 & 9 & 20.847 & 135.892 & .000 \\
Available $\mathrm{P}_{2} \mathrm{O}_{5}$ & 330.608 & 9 & 36.734 & 1446.707 & .000 \\
Exchageable $\mathrm{K}_{2} \mathrm{O}$ & 3128.922 & 9 & 347.658 & 1341273.227 & .000 \\
Total Corg & 4418.506 & 9 & 490.945 & 46693.755 & .000 \\
Corg in total HS & 604.263 & 9 & 67.140 & 18407.977 & .000 \\
Cresidue & 1528.617 & 9 & 169.846 & 4214.825 & .000 \\
Total N & 390240.462 & 9 & 43360.051 & 131.769 & .000 \\
Total P & 210089.032 & 9 & 23343.226 & 583.232 & .000 \\
\hline
\end{tabular}

Mineral nitrogen reserves varied significantly on account of the dynamics of bulk density and depth of the layers constructing respective genetic horizons (Table 2). The data shows increasing of available nitrogen forms and their reserves down the profile at the end of the transition horizon. This data confirm our previous results on Haplic Chernozems (slightly leached) where at the same depth was formed the $1^{\text {st }}$ maximum of accumulation of mireneral nitrogen [29].

Humus-accumulative horizon $\left(\mathrm{A}_{0-84 \mathrm{~cm}}\right)$ characterized with the greatest reserves of mineral nitrogen accessible for the plants, as well as potential $\mathrm{N}$-supplying ability after 56 days of incubation. More than $80 \%$ from the formed reserves were in ammonium form (Fig. 2). 
Table 2 Mineral $\mathrm{N}$ forms and pure Mineralization ability reserves by genetic horizons down the profile of Haplic Chernozems (Krupen, Kavarna town)

\begin{tabular}{llllll}
\hline Horizon & Depth $\mathbf{c m}$ & $\begin{array}{l}\mathbf{N H}_{4}-\mathbf{N} \\
\mathrm{g} / \mathrm{m}^{2}\end{array}$ & $\mathbf{N O}_{3}-\mathbf{N}$ & Sum & $\begin{array}{l}\text { Pure MA after 56 days incubation } \\
\mathrm{kg} / \mathrm{m}^{2}\end{array}$ \\
\hline $\mathrm{Ah}$ & $0-8$ & $440.32 \mathrm{a}$ & $73.32 \mathrm{a}$ & $513.64 \mathrm{a}$ & $8.23 \mathrm{e}$ \\
$\mathrm{A}_{1}$ & $8-24$ & $796.58 \mathrm{~cd}$ & $122.88 \mathrm{c}$ & $919.45 \mathrm{c}$ & $10.92 \mathrm{~g}$ \\
$\mathrm{~A}_{2}$ & $24-42$ & $801.80 \mathrm{~cd}$ & $124.58 \mathrm{c}$ & $926.38 \mathrm{c}$ & $10.10 \mathrm{f}$ \\
$\mathrm{A}_{3}$ & $42-67$ & $717.60 \mathrm{bc}$ & $170.09 \mathrm{~g}$ & $887.69 \mathrm{bc}$ & $6.53 \mathrm{~d}$ \\
$\mathrm{AB}$ & $67-84$ & $498.17 \mathrm{ab}$ & $114.81 \mathrm{~b}$ & $612.98 \mathrm{a}$ & $2.31 \mathrm{a}$ \\
$\mathrm{B}_{1}$ & $84-105$ & $562.63 \mathrm{ab}$ & $133.09 \mathrm{~d}$ & $695.72 \mathrm{ab}$ & $3.14 \mathrm{~b}$ \\
$\mathrm{Bk}_{2}$ & $105-120$ & $456.21 \mathrm{a}$ & $69.26 \mathrm{a}$ & $525.47 \mathrm{a}$ & $2.74 \mathrm{ab}$ \\
$\mathrm{BCk}$ & $120-152$ & $987.46 \mathrm{de}$ & $195.27 \mathrm{~h}$ & $1182.73 \mathrm{~d}$ & $4.54 \mathrm{c}$ \\
$\mathrm{Ck}$ & $152-178$ & $1033.62 \mathrm{e}$ & $147.16 \mathrm{e}$ & $1180.78 \mathrm{~d}$ & $3.18 \mathrm{~b}$ \\
$\mathrm{Ck} 2$ & $178-195$ & $928.84 \mathrm{cde}$ & $158.98 \mathrm{f}$ & $1087.82 \mathrm{~cd}$ & $3.23 \mathrm{~b}$ \\
\hline
\end{tabular}

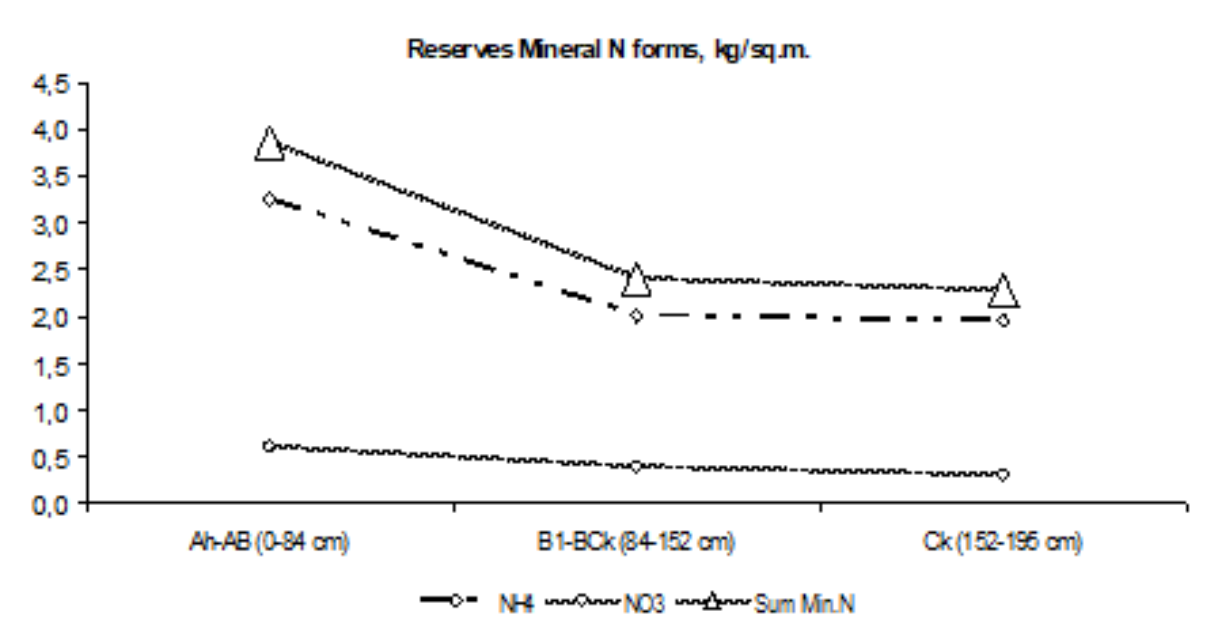

Mineral Nitrogen forms

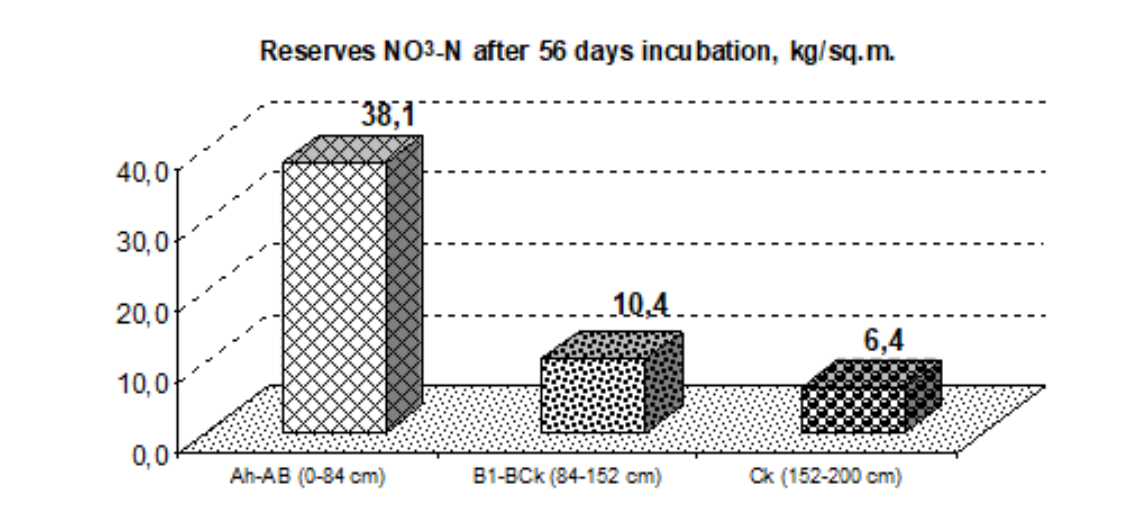

Pure Mineralization ability reserves after 56- days incubation

Figure 2 Nitrogen reserves by A-B-C horizons down the profile of Haplic Chernozems (Krupen, Kavarna town) 
Phosphorus and potassium reserves avilablable for plants are under high dynamic of values (Table 3). The concentration of this macroelements decreased down the profile depth. The main role for the formation of the reserves is both, the depth of the genetic horizons and the bulk density.

Table 3 Available phosphorus and exchangeable potassium reserves by genetic horizons down the profile of Haplic Chernozems (Krupen, Kavarna town).

\begin{tabular}{llll}
\hline Horizon & Depth, cm & $\begin{array}{l}\mathbf{P}_{\mathbf{2}} \mathbf{O}_{\mathbf{5}} \\
\mathbf{g} / \mathbf{m}^{2}\end{array}$ & $\mathbf{K}_{\mathbf{2}} \mathbf{O}$ \\
\hline $\mathrm{Ah}$ & $0-8$ & $6.29 \mathrm{e}$ & $27.52 \mathrm{a}$ \\
$\mathrm{A}_{1}$ & $8-24$ & $4.29 \mathrm{~d}$ & $53.19 \mathrm{~g}$ \\
$\mathrm{~A}_{2}$ & $24-42$ & $2.86 \mathrm{~b}$ & $47.95 \mathrm{e}$ \\
$\mathrm{A}_{3}$ & $42-67$ & $3.45 \mathrm{c}$ & $64.27 \mathrm{~h}$ \\
$\mathrm{AB}$ & $67-84$ & $2.45 \mathrm{a}$ & $50.67 \mathrm{f}$ \\
$\mathrm{B}_{1}$ & $84-105$ & $3.09 \mathrm{~b}$ & $53.21 \mathrm{~g}$ \\
$\mathrm{Bk} 2$ & $105-120$ & $3.03 \mathrm{~b}$ & $38.29 \mathrm{~b}$ \\
$\mathrm{BCk}$ & $120-152$ & $8.59 \mathrm{f}$ & $73.66 \mathrm{i}$ \\
$\mathrm{Ck}$ & $152-178$ & $9.05 \mathrm{~g}$ & $39.99 \mathrm{c}$ \\
$\mathrm{Ck}_{2}$ & $178-195$ & $16,00 \mathrm{~h}$ & $43,78 \mathrm{~d}$ \\
\hline
\end{tabular}

In Humus-accumulative horizon were concentrated $26.48 \%$ from the phosphorus reserves easy of access for the plants and $48.10 \%$ - from those of exchanengeable potassium (Fig. 3).

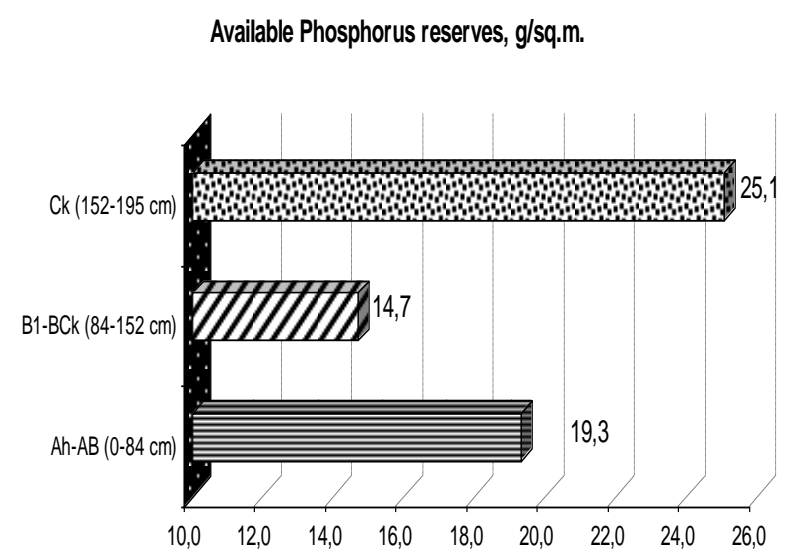

Available phosphorus

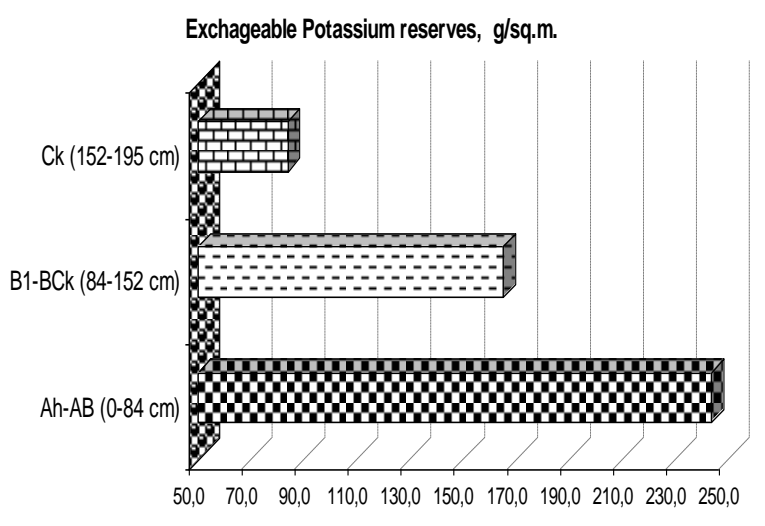

Exchangeable potassium

Figure 3 Reserves of available forms of phosphorus and potassium by A-B-C horizons down the profile of Haplic Chernozems (Krupen, Kavarna town), g/m. sq.

The investigated profile of virgin Haplic Chernozems is also marked by a large variation in total nitrogen and phosphorus reserves throughout the depth (Table 4). The soil formation materials are characterized by the lowest stock size. The largest total nitrogen reserves are concentrated in the $A_{2}$ and $A_{3}$ sub-horizons. A similar tendency is observed for stocks of total phosphorus, but with the maximum value of the stocks of this nutrient is established at the lower end of the transition sub-horizon ( $\mathrm{BC}_{\mathrm{k}}$ ). Moise and Lungu [49] established for the region of Constanta (North Dobrudzha) that in the arable Chernozem humus content was recorded from 3.1 to $4 \%, 0.145 \%$ phosphorus and $0.186 \%$ nitrogen contents. These results are relatively similar to those obtained in different research years in Dobrudzha Agricultural Institute for the region of South Dobrudzha [28, 30, 34$]$. 
With the lowest reserves of total phosphorus, the surface soil layer $\left(A_{h}\right)$ is distinguished. The main reason for this is that the soil is in virgin condition, i.e no phosphorus fertilizers has been introduced to increase its concentration. On the other hand, the power of $A_{h}$ is small, only $8 \mathrm{~cm}$, which also plays a significant role in determining the size of the stocks.

Table 4 Total Nitrogen and Phosphorus reserves by genetic horizons down the profile of Haplic Chernozems (Krupen, Kavarna town)

\begin{tabular}{llll}
\hline \multirow{2}{*}{ Horizon } & Depth, cm & Total $\mathbf{N}$ & Total $\mathbf{P}_{2} \mathbf{O}_{5}$ \\
\cline { 3 - 4 } & & $\mathbf{g} / \mathbf{m}^{2}$ & \\
\hline $\mathrm{Ah}$ & $0-8$ & $282.60 \mathrm{c}$ & $182.43 \mathrm{a}$ \\
$\mathrm{A}_{1}$ & $8-24$ & $454.97 \mathrm{e}$ & $360.91 \mathrm{~d}$ \\
$\mathrm{~A}_{2}$ & $24-42$ & $508.25 \mathrm{f}$ & $369.50 \mathrm{~d}$ \\
$\mathrm{~A}_{3}$ & $42-67$ & $564.46 \mathrm{~g}$ & $469.55 \mathrm{~g}$ \\
$\mathrm{AB}$ & $67-84$ & $344.87 \mathrm{~d}$ & $340.15 \mathrm{c}$ \\
$\mathrm{B}_{1}$ & $84-105$ & $303.39 \mathrm{c}$ & $373.71 \mathrm{~d}$ \\
$\mathrm{Bk}$ & $105-120$ & $187.47 \mathrm{~b}$ & $279.58 \mathrm{~b}$ \\
$\mathrm{BCk}_{2}$ & $120-152$ & $313.30 \mathrm{~cd}$ & $592.25 \mathrm{~h}$ \\
$\mathrm{Ck}$ & $152-178$ & $141.29 \mathrm{a}$ & $371.27 \mathrm{~d}$ \\
$\mathrm{Ck}_{2}$ & $178-195$ & $146.53 \mathrm{a}$ & $410.49 \mathrm{f}$ \\
\hline
\end{tabular}

The $\mathrm{N}_{\text {total }}$ reserves varied from $66.37 \%$ in $A_{\text {horizon }}$ to $8.86 \%$ in $C_{\text {horizon }}$ (Fig. 4). The reserves of total phosphorus in $\mathrm{A}_{0-84} \mathrm{~cm}$ add up to $1.723 \mathrm{~kg} / \mathrm{m}^{2}$, which is $45.94 \%$ from the total reserves of through profile, while in soil formatting material horizon (Chorizon) reached to $0.782 \mathrm{~kg} / \mathrm{m}^{2}(20.85 \%)$.

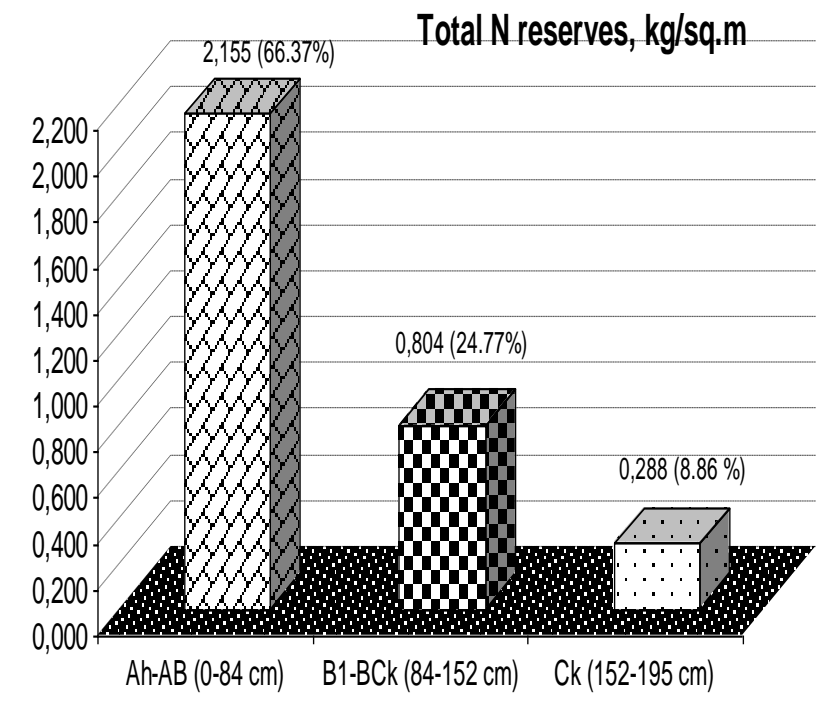

Nitrogen
Total $\mathrm{P}$ reserves, $\mathrm{kg} / \mathrm{sq} . \mathrm{m}$.

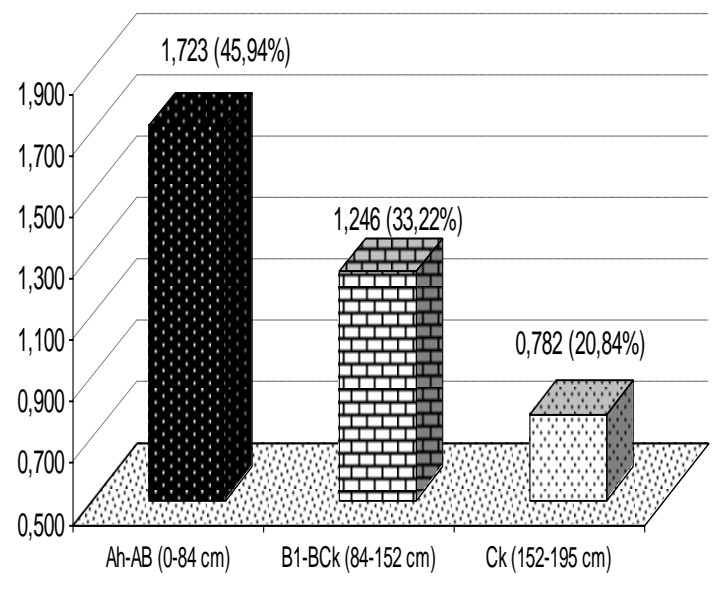

Phosphorus

Figure 4 Total Nitrogen and Phosphorus reserves by A-B-C horizons down the profile of Haplic Chernozems (Krupen, Kavarna town) 
Already in 1896 in the report to the Department of Agriculture of USA Snyder notes that a virgin soil or one recently cleared may show a high state of productiveness for a number of years after it is brought under cultivation. Gradually, however, a decline in fertility is observed, which is slight at first, but more marked after a lapse of fifteen or twenty years [50]. The author points out that agriculturally considered, the two most important points regarding the composition of humus are the presence of nitrogen as a constant constituent, and the chemical union of the humus with potash, lime, and phosphoric acid, forming humâtes.

Soil organic matter is a complex system and composed of organic compounds, differing in mechanisms of their fixation in the soil and in their functions in carbon cycling and soil formation [51,52]. Literature data about changes in soil carbon stocks due to land use changes are frequently discussed in review articles [53, 54, 55]. The data from our study show that organic carbon stocks in the studied soil profile are gradually decreasing in depth (Table 5). The established carbon stocks of total humic substances $\left(\mathrm{C}_{\mathrm{THS}}\right)$ and carbon of the insoluble residue $\left(\mathrm{C}_{\text {residue }}\right)$, as one of the main characteristics of the composition of the soil organic matter, follow the same trend. In their investigations Duchaufour and Kuntze et al. [56, 57] also established the slightly decreasing of organic matter content with depth. This phenomenon is defined as isohumism. The essential process of evolution of this organic matter is a long maturation of various humic compounds, called melanization. [58, 59].

Table 5 Carbon groups reserves by genetic horizons down the profile of Haplic Chernozems (Krupen, Kavarna town).

\begin{tabular}{lllll}
\hline Horizons & Depth, cm & $\begin{array}{l}\text { Org. Ctotal } \\
\text { g/m² }\end{array}$ & C \\
& & $27.59 \mathrm{~d}$ & $10.32 \mathrm{~d}$ & $17.27 \mathrm{e}$ \\
\hline $\mathrm{Ah}$ & $0-8$ & $48.12 \mathrm{~h}$ & $18.32 \mathrm{~h}$ & $29.79 \mathrm{~h}$ \\
$\mathrm{~A}_{1}$ & $8-24$ & $51.34 \mathrm{i}$ & $21.97 \mathrm{i}$ & $29.37 \mathrm{~g}$ \\
$\mathrm{~A}_{2}$ & $24-42$ & $56.41 \mathrm{j}$ & $25.06 \mathrm{j}$ & $31.35 \mathrm{i}$ \\
$\mathrm{A}_{3}$ & $42-67$ & $36.68 \mathrm{~g}$ & $18.00 \mathrm{~g}$ & $18.68 \mathrm{f}$ \\
$\mathrm{AB}$ & $67-84$ & $31.45 \mathrm{f}$ & $15.44 \mathrm{e}$ & $16.01 \mathrm{~d}$ \\
$\mathrm{~B}_{1}$ & $84-105$ & $17.96 \mathrm{c}$ & $8.35 \mathrm{a}$ & $9.61 \mathrm{~b}$ \\
$\mathrm{Bk} 2$ & $105-120$ & $31.15 \mathrm{e}$ & $16.80 \mathrm{f}$ & $14.35 \mathrm{c}$ \\
$\mathrm{BCk}$ & $120-152$ & $12.26 \mathrm{a}$ & $8.95 \mathrm{~b}$ & $7.22 \mathrm{a}$ \\
$\mathrm{Ck}$ & $152-178$ & $13.18 \mathrm{~b}$ & $9.80 \mathrm{c}$ & $7.37 \mathrm{a}$ \\
$\mathrm{Ck} 2$ & $178-195$ & & & \\
\hline
\end{tabular}

The use of chernozems in agriculture has caused drastic changes in their properties and the proportion of nearly all soilforming processes. The mass of organic substances that entered the soil and their mineralization changed, the physical properties (for instance, the soil structure) and the water regime were transformed, and acidification and decalcification began to develop. It is therefore imperative that a periodic comparison be made between the state of the virgin land and those under intensive agricultural use. Orlov et al. [60] revised system of the humus status parameters of soils and their genetic horizons. The system of parameters of the soil humus status is an indispensable criterion of soil and land evaluation. The revised and specified system makes it possible to characterize the soil humus status and examine the mechanisms of humus accumulation and formation.

The total organic carbon stocks in the study profile are $326.131 \mathrm{~kg} / \mathrm{m}^{2}$ (Fig. 5). The redistribution of these stocks across horizons is as follows: in Ahorizon is focused 67.50\% of these stocks, in transition horizon (B) - 24.70\% and in soil formation material (C) - 7.80\%. In a large scale investigation on the relationship between organic carbon content and soil type in the soils of Serbia Vidojević et al. [61] found out one of the largest SOC stocks for the soil layers $0-30 \mathrm{~cm}$ in Chernozems - $230.43 \times 10^{12} \mathrm{~g}$.

The distribution of total humic substances by genetic horizons in profile Krupen is as follows: in the humusaccumulative horizon (A) $-61.22 \%$, in the transitional (B) $-26.52 \%$ and in soil-forming materials (C) $-12.25 \%$ of the formed stocks in the order of $153.010 \mathrm{~kg} / \mathrm{m}^{2}$. 


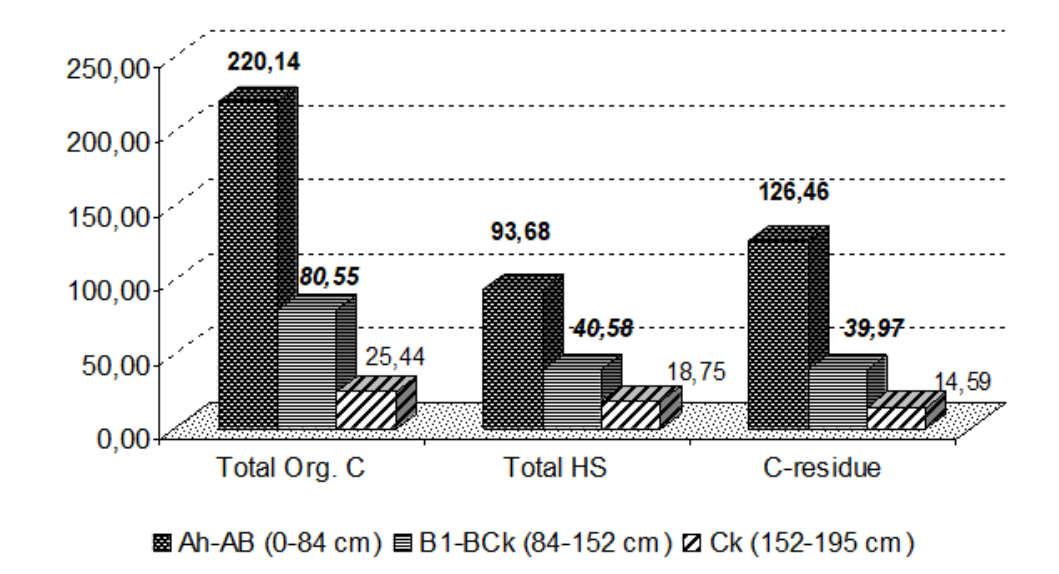

Figure 5 Carbon groups reserves by A-B-C horizons down the profile of Haplic Chernozems (Krupen, Kavarna town)

The insoluble residue ( $\mathrm{C}_{\text {residue}}$ ) of organic matter in the soil is its essential characteristic. Our results show that, on average, $54.91 \%$ of the total organic carbon stocks in this soil profile fall precisely in the humus guardian group. The total amount of $\mathrm{C}_{\text {residue }}$ in the profile is $181.023 \mathrm{~kg} / \mathrm{ha}$, with $69.86 \%$ of it being concentrated in the humus accumulative horizon (A).

Based on our research we found that the degree of humus enrichment with nitrogen is "average" along the entire depth of the profile. In humus accumulative horizon (A) the average value is 10.21. In the transition (B - 9.96) and soil-forming materials ( $\mathrm{C}$ - 8.84) the values decrease, which is an indication of a slight tendency to enrich the organic matter with nitrogen. Summary of soil organic matter in Bulgaria processes of humification and organic carbon stocks by soil groups and types were developed by Professor Filcheva $[16,62,63]$.

The analysis of the coefficients of variation showed that the mean values of nitrogen mineral forms and theirs sum, for exchangeable potassium and total phosphorus were approximately homogeneous and is characterized by a mean dispersion of the trait (CV-30\%) (Fig. 6). The coefficients for the values of total nitrogen and the composition of the soil organic matter are below 50\% and they are sufficiently representative. The highest dispersion was found in the available phosphorus and potential $\mathrm{N}$ applying ability after a 56-day incubation values - more than $50 \%$. This means strongly heterogeneous excerpt (large sign dispersing).

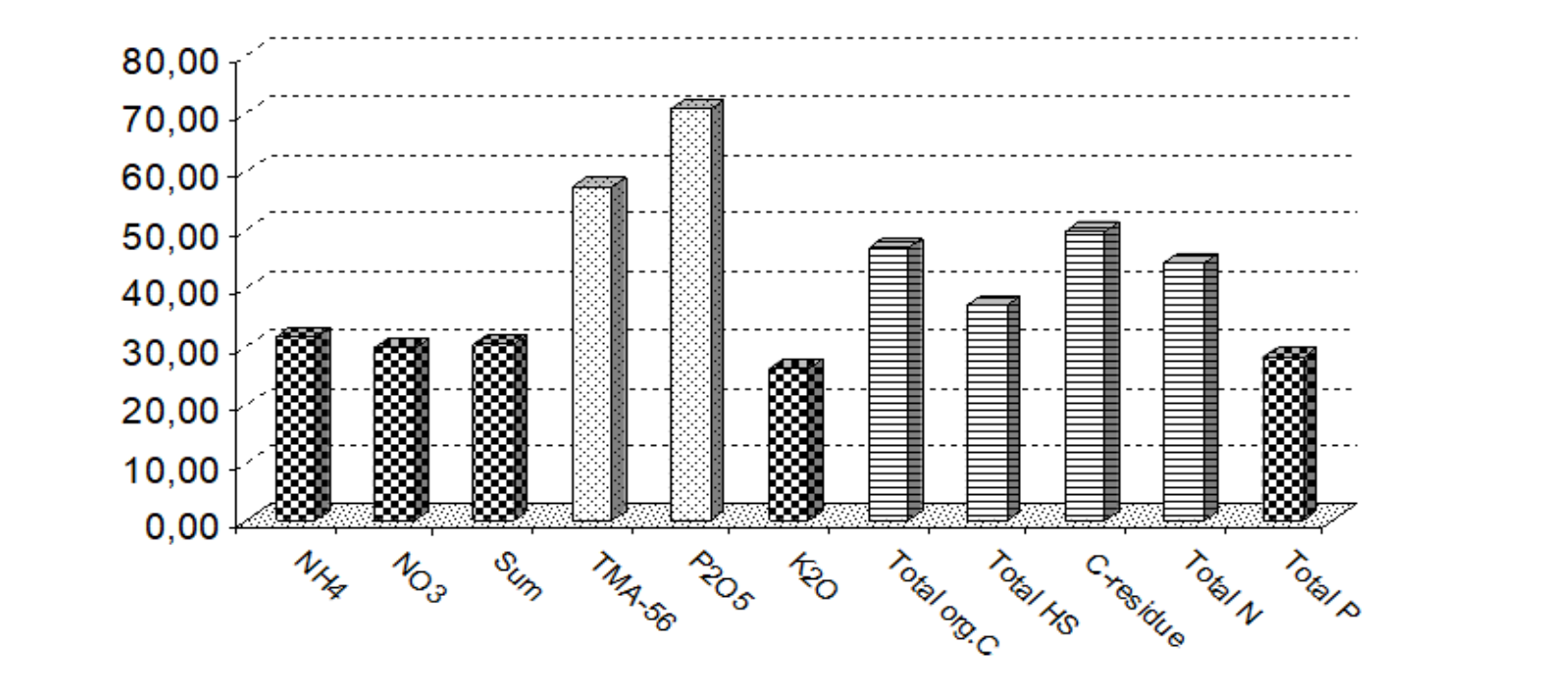

Figure 6 Coefficients of variation by indices for the whole profile

We established very well expressed positive correlations between total org.C reserves with total nitrogen, C-THS and C-residue (Fig. 7). The positive correlations exist also between total organic $\mathrm{C}$ reserves with exchangeable $\mathrm{K}$ and 
potential N-supplying ability. The correlation between total organic $\mathrm{C}$ reserves and those with available phosphorus are strongly negative.

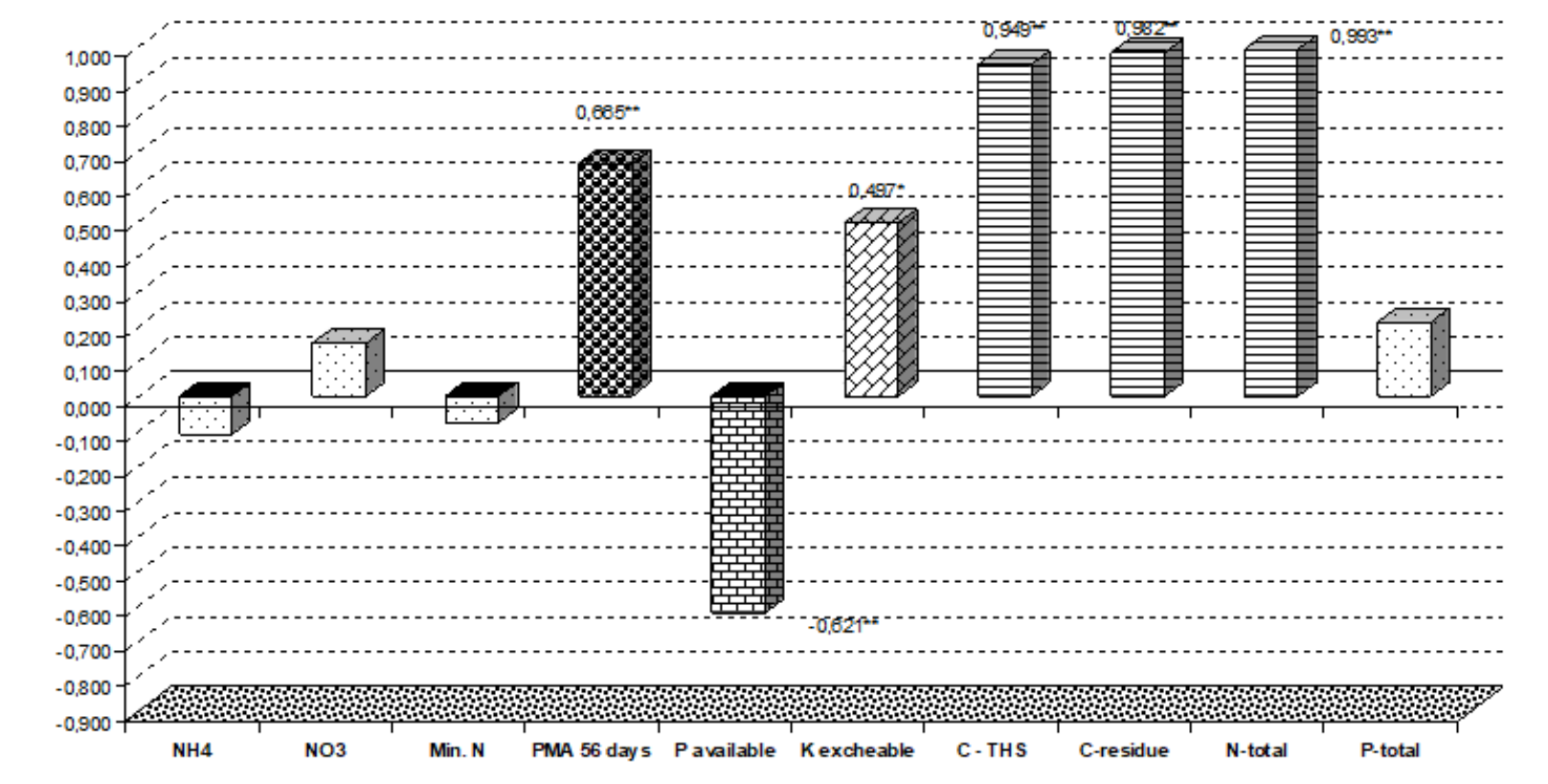

Figure 7 Correlations between total $C_{\text {org }}$ reserves with reserves of available and total nutrients and some groups of Corg in the investigated profile of Haplic Chernozems

\section{Conclusion}

Our study on the virgin soil profile is representative of Haplic Chernozems in South Dobrudzha and confirms our previous investigations that they are one of the most fertility soils in Bulgaria. The profile is also marked by a variation of nutrients reserves according to the genetic horizon. The reserves for both, nutrients and soil organic matter gradually decreased which is typical for the group of izohumic soils. The $\mathrm{N}_{\text {total }}$ reserves varied from $66.37 \%$ in $\mathrm{A}_{\text {horizon }}$ to $8.86 \%$ in Chorizon of the total stocks amounting to $3.247 \mathrm{~kg} / \mathrm{ha}$. The reserves of total phosphorus in $\mathrm{A}_{0-84} \mathrm{~cm}$ add up to $1.723 \mathrm{~kg} / \mathrm{m}^{2}$, which is $45.94 \%$ from the total reserves of through profile, while in soil formating material horizon ( $\mathrm{C}_{\text {horizon}}$ ) reached to $0.782 \mathrm{~kg} / \mathrm{m}^{2}(20.85 \%)$. The organic carbon reserves in the studied profile $(0-195 \mathrm{~cm})$ are $326.131 \mathrm{~kg} / \mathrm{m}^{2} \mathrm{and} 67.50 \%$ of the stocks are concentrated in the humus accumulation horizon. In transition horison (B84-152) all nutrients reserves gradually decreased and reached lowest values in soil formation material horizon $\left(\mathrm{C}_{152-195}\right)$. These two genetic horizons have a higher degree of enrichment of the humus with nitrogen compared to the humus-accumulative horizon. Throughout the depth of the profile, the degree of enrichment of humus with nitrogen is defined as "average". We established essential correlations between the investigated indicesas follows: Reserves of C-total are in a strong correlation with reserves of $\mathrm{N}$-total $\left(0.993^{* *}\right)$; Cres. $\left(0.982^{* *}\right)$; C-THS $\left(0.949^{* *}\right)$; mineralization ability after 56 days incubation $\left(0.665^{* *}\right)$ and exchable potassium.

\section{Compliance with ethical standards}

\section{Acknowledgments}

The authors express thanks to the Agrospectar-Kavarna Company, the Bulgarian Humic Substances Society, the Dobrudzha Agricultural Institute - Generdl Toshevo and the Institute of Soil Science, Agrotechnology and Plant Protection "Nicola Pushkarov" - Sofia for their empathy and support.

\section{Disclosure of conflict of interest}

There is no any conflict to interest in preparing and publishing the article. 


\section{References}

[1] Jobbagy EG and RB Jackson. (2001). The distribution of soil nutrients with depth: Global patterns and the im, 2001. print of plants Biogeochemistry, 53, 51-77.

[2] Tarnocai C, JG Canadell, E Schuur, P Kuhry, G Mazhitova and S Zimov. (2009). Soil organic carbon pools in the northerncircumpolar permafrost region, Global Biogeochem. Cy, 23, 11.

[3] Janssens IA, W Dieleman, S Luyssaert, JA Subke, M Reichstein, R Ceulemans, P Ciais, AJ Dolman, J Grace, G Matteucci, D Papale, SL Piao, ED Schulze, J Tang and Law BE. (2010). Reduction of forest soil respiration in response to nitrogen deposition, Nat. Geosci., 3, 315-322.

[4] Schimel DS. (1995).Terrestrial Ecosystems and the Carbon-Cycle. Glob. Change Biol, 1, 77-91.

[5] Tarnocai C, JG Canadell, EAG Schuur, P Kuhry, G Mazhitova and S Zimov. (2009). Soil organic carbon pools in the northern circumpolar permafrost region. GLOBAL BIOGEOCHEMICAL CYCLES, 23, 1-11, GB2023,

[6] Kononova MM. (1966). Soil Organic Matter: It's Nature, Its Role in Soil Formation and in Soil Fertility. Pergamon Press Ltd., Oxford, 45-49.

[7] Kononova MM. (1975). Humus in virgin and cultivated soils. In: Soil Components, vol. I Organic Components, ed. by J. E. Gieseking, Springer-Verlag, Berlin, 497-526.

[8] Dokuchaev VV. (1883). Russkij Cernozem. Sankt Petersburg.

[9] Dokuchaev VV. (1900). Collection pédologique - Zones verticales des sols - Zones agricoles - Sols du Caucase. Exposition universelle Paris 1900 Section russe - Saint Petersbourg - Guide scientifique sommaire de la section pédologique russe à l'Exposition Universelle de 1900 à Paris. Ministère de l'Agriculture Saint-Petersbourg, Sankt Petersburg.

[10] Reintamn L. (2001). Soil stories from Swedish time up to present in: Historiae Scientiarum Baltica. Abstract of the XV Baltic Conference on the History of Science. Tartu, 30-31, 141-144.

[11] Vysloužilová B, D Ertlen, D Schwartz and L Šefrna. (2016). Chernozem. From concept to classification: a review AUC Geographica, 51(1), 85-95.

[12] Papish. (2017). Differntiation of the material composition of Lviv region luvic greyzemic Chernozems (Ukraine). Polish Journal of Soil Science, 1, 11-20.

[13] Yigini Y and Panos P. (2016). European Commission Joint Research Centre, Land ResourceAssessment of soil organic carbon stocks under future climate and land cover changes in Europe. Science of the Total Environment, 557-558, 838-850.

[14] Hristov B and Ekaterina F. (2017). Soil organic matter content and composition in different pedoclimatic zones of Bulgaria. Eurasian J Soil Sci, 6(1), 65 - 74.

[15] Filcheva E. (2004). Comparative characteristics of soils in Bulgaria in content, composition and stocks of organic matter. Habilitation thesis for the award of Academic title Prof., NCAS, ISS "N. Poushkarov ", Sofia, 263.

[16] Filcheva E. (2007). Characteristics of soils in Bulgaria by content, composition and organic matter stocks. Grouping of soils in Bulgaria. ISBN 978-954-8702-11-9. "Minerva”-Sophia, 191.

[17] Filcheva E. (2018). Organic matter content and quality of Bulgarian soils. In: Filcheva E. et al. (Eds.). Book of Abstracts, ISBN 978-619-90189-3-4, BHSS, 19IHSS Conference, Albena, Bulgaria, 16-21, 99-100.

[18] Nankova M and Ivaylo K. (1992). Influence of soil tillage systems on the humus status of slightly leached chernozem in the region of Dobrudja. Soil science, Agrochemistry and Ecology, 27(2), 40-43.

[19] Nankova M and Ivaylo K. (1992). Study of the influence of soil tillage systems in crop rotation on the fertility of slightly leached chernozem in Dobrudja. Soil science, Agrochemistry and Ecology, 27(4), 46-48.

[20] Nankova M. (1995). Fractional composition of humus of slightly leached chernozem depending on long-lasting mineral fertilization and type of crop rotation. I. Impact of Mineral Fertilization. Soil Science, Agrochemistry and Ecology, 3, 112-114.

[21] Nankova M. (1995). Fractional composition of humus of slightly leached chernozem depending on long-term mineral fertilization and type of crop rotation. II. Effect of type of crop rotation. Soil Science, Agrochemistry and Ecology, 21(3), 115-117. 
[22] Nankova M, P Yankov, E Penchev and R Djendova. (1997). Humus fraction composition of the slightly leached chernozem in cheseling according to the size of soil units. $11^{\text {th }}$ World fertilizer Congress 7-13 September, Gent BELGIUM, 239-246.

[23] Nankova M, Christofor K and Emil P. (1999). Effect of long-term fertilization with different norms and rates of nutrients on slightly leached chernozem fertility. XXVIXth Annual ESNA Meeting, September 7-12, Wye, Kent (UK), 20-26.

[24] Nankova M, Djendova R, Kirchev C and Penchev E. (1999). Effect of long-term nutrition elements norms and ratios on humic condition of the slightly leached chernozem in Dobroudja. XXVIXth Annual ESNA Meeting, September 7-12, Wye, Kent (UK), 27-33.

[25] Nankova M, P Yankov, D Georgiev and N Nankov. (2010). Role of some agronomy practices in the nutrition regime of Haplic Chernozems after spring crops. 15-th International Symposium on Environmental Pollution and its Impact on Life in the Mediterranean Region: Prfblems and Solutions, October, 2009, Bary, ITALY; Fresenius Environmental Bulletin, 19(8b), 1715-1721.

[26] Nankova M. (2010). Long-term mineral fertilization and its effect on humus conditio of the Haplic Chernozems in Dobroudja. "ADVANCES IN NATURAL ORGANIC MATTER AND HUMIC SUBSTANCES RESEARCH 2008-2010", XV Meeting of the International Humic Substances Society, Puerto de la Cruz, Tenerife, Canary Island, 419-423.

[27] Nankova M. (2011). Humic fractions composition of Haplic Chernozems in Dobrudzha region under 40-years systematic mineral fertilization. "Humus substances - News in Sience and Practice", $3^{\text {rd }}$ Nat. Conference with International Conference 12-16 September, 2011, Sofia.Soil Science Agrochemistry and Ecology, Supplement № 1(4), 179-184.

[28] Nankova M, P Yankov and Il Iliev. (2011). Content and reserves of total carbon in bipolar crop rotation formed during systematic 40-year mineral fertilization of Haplic Chernozems. International Conference "100 Years of Soil Science in Bulgaria", May 16-20, 2011, Sofia, part two 689-694.

[29] Nankova M. (2012). Long-Term Mineral Fertilization and Soil Fertility. Agricultural Science Edited by Dr. Godwin Aflakpui Publisher In Tech, Chapter 6, 97-118.

[30] Nankova M. (2012). Characterization of changes in soil acidity in a two-field crop rotation as a result of systemic mineral fertilization with different norms and ratios between nitrogen, phosphorus and potassium. National Scientific Conference "Contemporary Trends and Major Priorities in the Selection and Agro-Engineering of Field Crops", dedicated to the 60 Years of the Dobrudzha Agricultural Institute and 70 Years of Agricultural Science in Dobrudzha, Field Crops Studies, 7(2), 335 - 348.

[31] Nankova M, P Yankov, N Nankov, I Iliev, G Milev, A Ivanova and D Dimitrov. (2012). Current state of soil organic matter in South Dobrudzha. Third International Scientific Congress "50 Years of Technical University, Varna”, 0406 October, 2012, Varna, Bulgaria, 7,185-191.

[32] Nankova M and P Yankov. (2013). Long-term application of soil tillage systems in crop rotation and their effct on phosphorus distribution in the soil units of Haplic Chernozems. $2^{\text {nd }}$ International Scientific Conference Soil and Crop Management, September 26-28, 108-118.

[33] Nankova M and P Yankov. (2013). Long-Term Use of Soil Tillage Systems in Crop Rotation and Their Effect on The Distribution of Soil Organic Matter in The Soil Organic Matter in The Soil Units of Haplic Chernozems. Journal of Soil and Water Journal, 2, 2(1), 1201-1208.

[34] Nankova M, P Yankov and G Bankova-Atanasova. (2014). Content and reserves of total nitrogen and phosphorus forms in the upper part of the root-deep layer under 40-year systematic mineral fertilization in two-field crop rotation. Scientific works, Agricultural Academy, Institute of Agriculture - Karnobat, 3(1), 195-206.

[35] Nankova M and P Yankov. 2014. Investigation on the effect of plouging and some minimal soil tillages on the soil organic matter condition in the Haplic Chernozems. 17th IHSS Conference, Ioannina, Greece, 125-130.

[36] Nankova M and P Yankov. (2015). Independent and Combined Effect of Some Soil Tillage Systems on Nitrogen and Carbon Concentration in Soil Structural Units of Haplic Chernozems. Journal of Agricultural Science and Technology B 5 (2015), 457 - 468.

[37] Nankova M. (2018). Relationships between Haplic Chernozems mineralization ability and soil organic matter composition as a result from long-term systematic mineral fertilization. In: Proc. Second Int. Scientific Conference "Modern (Up to date) state of Chernozems.Rostov on Don - Taganrog, Publishing house of Southern Federal University, 322-331. 
[38] Filcheva E and R Ilieva. (2014). Soil organic matter of Bulgarian Chernozems. In: Proc. 17 th International Conference of IHSS, 1-5 September, Ioannina, Greece, 98-99.

[39] Filcheva E, R Ilieva, I Lubenova, B Hristov and M Hristova. (2018). Humus state of Bulgarian Chernozems. In: Proc. Second Int. Scientific Conference "Modern (Up to date) state of Chernozems. Rostov on Don, 69-76.

[40] Teoharov M, T Shishkov, B Hristov, E Filcheva, R Ilieva, I lubenova, V Krasteva, B Georgiev, M Banov, P Ivanov, M Hristova, Z Mitreva, I Kirilov and G Dimitrov. (2014). Chernozems in Bulgaria - systematics, peculiarities and problems. In Conf.: 130 years of Russian Chernozem. NTA, 01.10. 2013 г.; Soil Science, Agrochemistry and Ecology XLVIII, 3-4, 3 - 9.

[41] Teoharov M, T Shishkov, B Hristov, E Filcheva, R Ilieva, I lubenova, V Krasteva, B Georgiev, M Banov, P Ivanov, M Hristova, Z Mitreva, I Kirilov and G Dimitrov. 2015. Chernozems in Bulgaria - systematics, peculiarities and problems 20-34. In book: Chernozems in Bulgaria. Problems, Assessment, Use, and Protection ISBN 978-61990414-1-3, Sofia, 188.

[42] Shishkov T, E Filcheva, M Nankova, M Kercheva and E Dimitrov. (2019). Humus substances, physicochemicals properties and agrochemical characteristic of strongly leached chernozem from northeastern Bulgaria. Silva Balcanica, 20 (Special issue 1), 29-44.

[43] Palaveev T. D and T. P Totev. (1979). Soil acidity and agro methods for its neutralization. Sofia, 132-137.

[44] Agrochemical methods for investigation of soil. (1975). Moscow, (Ru).

[45] Ivanov P. (1984). A new acetate-lactate method for identification of plant available phosphorus and potassium in soil. Soil science and Agrochemistry, 4, 88-98.

[46] Filcheva EG and Tsadilas CD. (2002). Influence of clinoptilolite and compost on soil properties. Communications in Soil Science and Plant Analysis, 33 (3-4), 595-607.

[47] Orlov DS and LA Grisina. (1981). Practical Work in the Chemistry of Humus. Moscow, MGU. (in Russian)

[48] Post WM and KC Kwon. (2000). Soil carbon sequestration and land use change: processes and potential. Global Change Biology, 6, 317-328.

[49] Schrumpf M, E. D Schulze, K. Kaiser and .J Schumacher. (2011). How accurately can soil organic carbon stocks and stock changes be quantified by soil inventories? Biogeosciences, 8, 1193-1212.

[50] Moise I and M Lungu. (2013). Consideration on physical and chemical properties of typical chernozem from topraisar area, Constanta county and proposals to improve its use. Research Journal of Agricultural Science, 45(1), 34-39.

[51] Snyder HB. Sc. (1896). Humus in its relation to soil fertility. Yearbook of the U. S. Department of Agriculture. Farmers' Bulletins Nos. 16 and 21, 131-142.

[52] Bronick CJ and Lal R. (2005). Soil structure and management: a review. Geoderma, 124, 3-22.

[53] Bin Z and P Xin-Hua. (2006). Organic matter enrichment and aggregate stabilization in a severely degraded Ultisol after reforestation. Pedosphere, 6, 699-706.

[54] Post WM and KC Kwon. (2000). Soil carbon sequestration and land - use change: processes and potential. Global Change Biology, 6(3), 317 - 328.

[55] Guo LB and RM Gifford. (2002). Soil carbon stocks and land use change: a meta analysis. Global Change Biology, 8, 345-360.

[56] Laganiere J, DA Angers and D Pare. (2010). Carbon accumulation in agricultural soils after afforestation: a meta analysis. Global Change Biology, 16, 439-453.

[57] Duchaufour P. (1977). Pédologie. T. 1. Pédogénèse et classification. Masson, Paris.

[58] Kunyze H, J Niemann, G Roeschmann and G Schwerdtfeger. (1983). Bodenkunde, Dritte, verbesserte Auflage. Ed. Verlag Eugen Ulmer, Stuttgart.

[59] Mathieu C. (2009). Les principaux sols du monde, Editions TEC\&DOC. Ed. Lavoisier, Paris.

[60] Nêmec்ek J, L Smolikovå and M Kutlilek. (1990). Pedologie a paleopedologie. Academia, Praha.

[61] Orlov DS, ON Biryukova and MS Rozanova. (2004). Revised system of the humus status parameters of soils and their genetic horizons. Eurasian Soil Science, 8, 798-805. 
[62] Vidojević D, Maja M, Aleksandar Đ, Ljiljana N and Branislava D. (2017). Spatial distribution of soil organic carbon stocks in Serbia. Global Symposium on Soil Organic Carbon, Rome, Italy, 21-23.

[63] Filcheva E. (2014). Humusformation, composition of soil organic matter and organic carbon stocks in soil groups and soil types. (88-106). In book: Soil organic matter and fertility of Bulgarian soils. (S. Krastanov et al.), 1-0, 470.

[64] Filcheva E. (2015). Characteristics of Soil Organic Matter of Bulgarian Soils. Lap Lambert Academic publishing ISBN 978-3-659-51204-9, 177.

\section{How to cite this article}

Nankova M. I and Filcheva E. G. (2020). Reserves of nutrients and soil organic components of Haplic Chernozems. GSC Biological and Pharmaceutical Sciences, 11(2), 139-152. 